\title{
Legal Protection for Children with Disabilities as a Victim of Sexual Violence
}

\author{
Satria Unggul Wicaksana Prakasa ${ }^{1 *}$, Aulia Septias ${ }^{1}$ \\ ${ }^{1}$ Faculty of Law, Muhammadiyah University of Surabaya, Surabaya, Indonesia \\ *Corresponding author.Email: satria@fh.um-surabaya.ac.id
}

\begin{abstract}
There is a legal fact that children with disabilities have the highest level of vulnerability to violence, especially sexual violence, in Indonesia it is increasing every year. Indonesia as a legal state that has the obligation to protect, respect and fulfill the rights of children with disabilities. The Indonesian state has ratified several conventions relating to children with disabilities. The research objective was to determine the form of legal protection and legal efforts for children with disabilities as victims of sexual violence, the research method used was normative juridical with a statute approach, the results of the first research on the form of legal protection for children with disabilities who became victims of sexual violence namely that children with disabilities should get the protection of their rights as victims of acts of sexual violence. The legal efforts that can be taken through 2 (two) paths are non-litigation (diversion) and litigation (investigation, prosecution and examination in court) and the restoration of victims' rights through the process of social rehabilitation.
\end{abstract}

Keywords: protection, children, disability, sexual violence

\section{INTRODUCTION}

Children with disabilities are children who have privileges that are not owned by children in general. International involvement in the protection of children with disabilities is regulated in the CRPD (Disability, United Nations) and has been ratified through the Law of the Republic of Indonesia Number 19 of 2011 Regarding the ratification of the Convention on the Right of Persons with Disabilities, not only that the Indonesian government together with the Parliament has made Law Number 8 of 2016 concerning Persons with Disabilities to protect the rights of people with disabilities [6].

Komnas Perempuan Annual Record (CATAHU) 2018 shows that there are 48 cases of women with disabilities experiencing violence handled by these institutions as many as 44 , with details of 13 cases of sexual violence in the form of sexual violence, 16 cases of sexual violence in the form of rape, 2 cases of abuse, 2 cases of physical violence, 3 cases of Domestic Violence, 4 cases of molestation, 2 cases of incest, and 1 case of fraud, violence in courtship, neglect, psychic, divorced husband, and human trafficking [7].

In early January 2019, in Tanjungjabung Timur, Jambi was shaken with a report about sexual abuse experienced by children with disabilities. This incident occurred in one of the dormitories, from a statement received by victims who experienced sexual harassment, there were 10 SLB students (Special Schools). The perpetrator was one of the employees who worked as a caretaker at the SLB for 5 years (Sultan, 2019). Related to the above problems, the legal protection of children with disabilities as victims of sexual violence with legal facts, one of which is sexual violence experienced by children as persons with disabilities which results in the loss of one of their rights, through the writing of a thesis entitled
"Legal Protection for Disabled Children as Victims of Violence Sexual ".

\section{RESEARCH METHODS}

This research method uses a statute approach. What is meant by the statutory approach is an approach using legislation and regulations relating to the legal issues being faced.

\section{DISCUSSION}

\subsection{Forms of Protection for Children with Disabilities as Victims of Sexual Violence}

The Child protection is all activities to guarantee and protect children and their rights so that they can live, grow, develop, participate, optimally in accordance with human dignity and dignity, and get protection from violence and discrimination, according to article 1 number 2 of the Law Number 35 Year 2014 Jo Law Number 23 Year 2002. Children who are also classified as people with disabilities have a vulnerable and disadvantageous position, in this case what is meant less favorable is that children with disabilities experience a very high risk of experiencing disruption and criminal action [5]. The meaning of children with disabilities is regulated in Article 1 number 7 of Law Number 35 of 2014 concerning Amendment of Law Number 23 of 2002 concerning Child Protection, namely "Children with Disabilities are Children who have physical, mental, intellectual, or sensory limitations within a period of time a long time in interacting with the environment and the attitude of the community can meet obstacles that make it difficult to participate fully and 
effectively based on equal rights." Disability varies according to Law Number 8 of 2016, namely: a. People with physical disabilities, b. Persons with intellectual disabilities, c. People with mental disabilities: and / or, d. People with sensory disabilities

Related to the Human Rights (HAM) of children with disabilities, the rights of persons with disabilities are part of general human rights contained in international human rights instruments and national human rights. In the DUHAM and the International Convenient on Civil and Political Rights (ICCPR / Civil and Political Rights Convention) and the International covenant on Economic Social and Culture Rights (ICESCR / Covenant on Economic, Social and Cultural Rights) which as the main instrument there is no clause equality and which explicitly mentions disability as a protected category, rights which are regulated only in general rights. Although it does not explicitly regulate persons with disabilities, the UDHR is shown as a framework for the protection of the rights within it, including the rights for persons with disabilities and in the Civil and Political Rights Covenant, basically strongly encouraging greater participation and freedom for all individuals and existing groups. Protection against ICESCR can also be found in the Standards Rules where these Standards Rules are very important and are valuable guidance to identify exactly what is the obligation of the participating countries. This understanding of rights is in line with the Covenant on the Right to Non-Discriminatory Treatment, which includes the elimination of various forms of discrimination which include persons with disabilities [1].

Children with disabilities also have the rights as regulated in Article 5 paragraph (3), namely that "children with disabilities have rights a. Get special protection from discrimination, neglect, harassment, exploitation, and sexual violence and crime; b. Get family care or care for a replacement family to grow back optimally; c. Protected interests in decision making; d. Childish treatment is in accordance with the dignity and rights of children; e. Meeting special needs; $f$. The same treatment with other children to achieve social integration and individual development; and g. Get social assistance.

If the right of a person with a disability is taken away by a person, that person will be subject to criminal sanctions in accordance with the criminal provisions in Article 145 which explains "Any person who obstructs and / or prohibits a person with a disability from obtaining the rights as referred to in Article 143 is convicted with a criminal penalty of imprisonment a maximum of 2 (two) years and a maximum fine of Rp. 200,000,000.00 (two hundred million rupiah).

\subsection{Legal Remedies for Children with Disabilities as Victims of Sexual Violence.}

Legal remedy is the right of a defendant or public prosecutor not to accept a court decision in the form of resistance or appeal or cassation or the right of a convicted person to submit a request for judicial review in terms of and in the manner stipulated in this Law, explained in the provisions of Article 1 Number 12 of the Law No. 8 of 1981 concerning
Criminal Procedure Law (Book of Criminal Procedure Law).

According to [2] legal remedy is an attempt by any individual or legal entity that feels that his rights or interests have been impaired to obtain justice and protection or legal certainty, according to the methods stipulated in the law. Meanwhile, according to [9], a legal effort is a business through legal channels from parties who feel dissatisfied with a judge's decision which he considers to be unfair or incorrect. The essence of the actual legal remedy is an effort or goal to help in solving problems so as to prevent things that will appear in a decision wrong. In the case of children with disabilities who experience violence, there are 2 forms of legal remedies, that is:

a. According to Law No. 8 of 1981 concerning Criminal Procedure (Litigation), that is:

1) Investigation

2) Prosecution

3) Item check

b. According to Law Number 11 of 2012 concerning the Criminal Justice System for Children. The process of resolving child cases in the SPPA Law is through litigation (investigation, prosecution, case examination in court) and Non-litigation (Diversion).

Diversion is derived from the English word "Diversion" which means diversion, which is then "Diversion" absorbed in the Indonesian language which is a diversion term. Diversion is pursued in every stage of the criminal procedure law so that children who are dealing with the law do not arrive at the judicial process in accordance with Article 6 letter $b$ of the SPPA Law.

The implementation of the version of the SPPA Law is emphasized by $\mathrm{ABH}$, that is, if the perpetrator and victim are children. In this case, children with disabilities are the same as children in general. The implementation starts from the investigation, prosecution to judicial process, the investigator, the public prosecutor and the judge in conducting diversion must consider, the category of criminal acts, the age of the child, the results of social research and environmental support of the family community, this is stated in Article 6 paragraph (2) Government Regulation Number 65 Year 2015.

Diversity is regulated in Government Regulation Number 65 of 2015 concerning Guidelines for the Implementation of Diversity and Handling of Children who are not yet 12 (Twelve) Years old. In the process investigation, prosecution, item check the essence according to the Criminal Procedure Code is that it is not at all possible diversion in it. The following are diversions carried out during the investigation, prosecution and litigation stages:

a. Investigation, POLRI investigators and PPNS investigators are given a new title, namely as special investigators for children, this is stipulated in Article 7 Jo Article 29 of Law Number 11 Year 2012 concerning the Criminal Justice System for Children [4]. In this case the emergence of special child investigators is a demand of Law Number 11 of 2012 concerning the Juvenile Justice System. The time period for diversion to be undertaken by a special investigator for children is no later than 7 (seven) days after the investigation begins. After attempting diversion to obtain approval, the diversion process can be carried out with a maximum 
period of 30 (thirty) days after commencement of diversion. In the case that the diversion process reaches an agreement, the investigator submits the minutes of the diversion, along with the agreement of the diversion to the head of the district court to be determined, whereas if the diversion is memorized then the investigator must continue the investigation and delegate the case to the public prosecutor by attaching the minutes of the diversion and the community research report [4].

b. Diversity at the prosecution level (Prosecution), Diversion at the prosecution level, which in principle was carried out after the prosecutor received the files from the police. So, in this case the public prosecutor is obliged to pay attention to the case files from the police and the results of community research that have been made by the community counselor and the obstacles that hinder the diversion process at the investigation level. For the diversion process, the public prosecutor is obliged to work for a diversion no later than 7 (seven) days after receiving the case file to the investigator and the diversion is to be held no later than 30 (thirty) days. [4]. According to Law Number 11 Year 2012 concerning the Juvenile Criminal System Article 42 paragraphs (3) and (4), In the case of a diversion process reaching an agreement, the Public Prosecutor submits the minutes of the Diversi along with the Diversi agreement to the head of the District Court to make a decision, and in In case the diversion fails, the Public Prosecutor is obliged to deliver the minutes of the Diversi and submit the case to the court by attaching a report on the results of the social research.

c. Diversification at the court examination stage (Item Check). Implementation of diversion in the court stage occurs if 2 (two) conditions are met, namely First, the diversion carried out at the prosecution stage fails to obtain an agreement. Second, the parties to the case have reached a diversion agreement at the Prosecution stage, but did not implement the diversion agreement they have reached. This refers to Article 52 of Law Number 11 Year 2012 concerning the Criminal Justice System for Children. The legal principle contained in Act Number 11 of 2012 concerning the Juvenile Criminal System requires that before entering the judicial process, law enforcers both Judges, Public Prosecutors, Police Investigators, and also Civil Servant Investigators (PPNS) and including Advocates those who are involved in the case of a child in conflict, the family and the community are all obliged to work on the settlement process outside the court or diversion based on the Restorative Justice approach [4]. The time period given to the Chief Justice to determine the Judge or Panel of Judges to handle the case of the Child is no later than 3 (three) days after receiving the case file from the Public Prosecutor. After the appointment of the Chairperson of the District Court, the Judge or Panel of Judges must seek Diversity no later than 7 (seven) days after the appointment of the Judge by the Head of the District Court, then the diversion process will take place within a maximum period of 30 (thirty) days. This is stated in Article 52 of Law Number 11 Year 2012 concerning the Criminal Justice System for Children. This means that when the case file is received by the Child Judge, within one week they will immediately implement diversion. If the Judge has determined the implementation of diversion, the Judge then orders the Public Prosecutor to present the Child, Parents / Guardians, Public Relations Advisor, Victim's Children, Victims' Parents / Guardians, Community Guidance Officers, Social Workers, Social Welfare Workers, Community Representatives. The presence of the Victim during the first trial was for the sake of the implementation of the diversion and then the presence of the victim at that stage was not the same as the presence of the victim as the examination of criminal cases in general at the Proof stage. However, at that stage the victim's presence was as a victim's witness to hear his statement. The juvenile judge is obliged to carry out diversion if the first hearing of the summoned parties has been present for a maximum period of 30 (thirty) days in the future.

d. Restoration of Victims' Rights

Regarding the process of recovery of children with disabilities as victims of sexual violence as well as children of victims of violence in general, namely rehabilitation of rehabilitation efforts. Rehabilitation is given in order to achieve a perfect recovery for victims who experience sexual violence according to Article 35 paragraph (2) Government Regulation of the Republic of Indonesia Number 40 of 2011 concerning Development, Assistance, and Recovery Against Children who are Victims or Perpetrators of Pornography, Social Rehabilitation is given in the form : a) Motivation and psychosocial diagnosis, b) Care and care, c) Vocational training and entrepreneurship coaching, d) Mental spiritual guidance , e) Physical guidance, f) Social guidance and psychosocial counselling, g) Accessibility services, h) Social assistance and assistance, i) Guidance for resocialization, j)Further guidance, k) References. Related to the stigma or ways that affect psychological recovery in child victims of sexual violence is in various ways [10]: (1) Personality Characteristics; (2) Support family / closest people and the community; (3) Beliefs and religions; (4) Activity or self-actualization; (5) Communication with stories; (6) Keep away from the scene.

The meaning of stigma or psychological recovery for $\mathrm{ABH}$ is to return to the normal community environment, namely as a child, which is well received by the community. Whereas for the Victim's Child, it is necessary to recover the name to minimize the traumatic impacts that it experiences and restore the rights of the victim's child such as playing with his peers and the child as a victim still gets the right to go to school like other children.

\section{CONCLUSION}

Form of legal protection for children with disabilities as victims of sexual violence is in the form of obtaining equal rights before the law and the right to get protection for nondiscrimination, neglect, abuse, exploitation and sexual violence and violence. This is regulated in Article 1 number 2 of Law Number 23 of 2002 Jo of Law Number 35 of 2014 concerning the Protection of children Jo of Article 26 Jo of Article 143 letter q Jo of Article 145 of Law Number 8 of 
[3] Catatan Tahunan tentang kekerasan terhadap perempuan . (2018). Retrieved from: Komisi Nasional Anti kekerasan terhadap perempuan.

[4] Dahlan, S. (2017). Penegakan Hukum dengan pendekatan diversi. Yogyakarta: Nusa Media.

[5] Maidin, G. (2012). Perlindungan hukum terhadap anak dan perempuan. Medan: PT. Refika Aditama.

[6] Nainggolan, Y. A., Widodo, M. F., Sari, E. N., B. A., \& iqbal, D. M. (2016). Rekam jejak kontribusi komnas HAM dalam pembentukan Undang-Undang No. 8 Tahun 2016 tentang penyandang disabilitas . Jakarta: Komisi Nasional Hak Asasi Manusia.

[7] Perempuan, K. (2018, 03 07). Catatan Tahunan Tentang Kekerasan Terhadap Perempuan. Date accessed 04 01, 2019, from Komisi Nasional Anti Kekerasan Terhadap Perempuan:

https://www.komnasperempuan.go.id/file/pdf_file/2018 /Publikasi/Catatan\%20Tahunan\%20Kekerasan\%20Terh adap\%20Perempuan\%202018.pdf

[8] Sultan, A. (2019, 1 1). Oknum Penjaga Asrama Ditangkap Usai Lecehkan 10 Siswa SLB. Date accessed 3 26, 2019, dari okenews:

https://news.okezone.com/read/2019/01/22/340/200768 9/oknum-penjaga-asrama-ditangkap-usai-lecehkan-10siswa-slb

[9] Tanugraha, D. S. (2013). Analisis Yuridis Putusan Bebas Karena Error In Persona (Studi Kasus Putusan Mahkamah Agung R.I. Nomor 90 Pk/Pid/2008). Purwokerto: Universitas Jenderal Soedirman.

[10] Yonanda, I. (27). Pemulihan psikologis pada korban kekerasan seksual . Yogyakarta: Universitas islam negeri sunan kalijaga. 